Acta Horticulturae et Regiotecturae - Special Issue

Nitra, Slovaca Universitas Agriculturae Nitriae, 2016, pp. 13-14

\title{
EFFECT OF ORANGE AND CINNAMON OIL ON THE OCCURRENCE AND HARMFULNESS OF THRIPS TABACI LIND ON ONION - PRELIMINARY RESULTS
}

\author{
Maria POBOŻNIAK*, Dominika GRABOWSKA, Marta OLCZYK
}

University of Agriculture in Krakow, Poland

\begin{abstract}
The aim of the present research work was to investigate the effect of orange and cinnamon oil on the occurrence and harmfulness of Thrips tabaci Lind on onion. In 2014, the nonchemical treatment was made with Prev-B2 (the concentration of 0.4\%), which contains: $4.2 \%$ of orange oil, $2.1 \%$ of boron and product Canol 70\% p/p exstract of Cinnamomum zeylanicum. In 2015, only Prev-B2 product was used. The standard sprayer was used and the treatments were done: twice in 2014 and three times in 2015. The thrips were collected directly from the leaves, using standard sweeping nets. The plants were examined to find the leave damages caused by feeding thrips. In 2014, Thrips tabaci was recorded from 11 June to 19 August, whereas in 2015 from 24 June to 4 August. Over two years of observations, the highest number of thrips was collected from onion growing on control plots (not treated with any preparation). Also, the mean percentage of areas damaged on the onion leaves was significantly higher on control plots than on plots treated with cinnamon oil in 2014 and orange oil in 2015.
\end{abstract}

Keywords: biological pesticides, organic farming, thrips, onion, essential oil

Although the production of onion during 2012-2014 noticed the decreasing trend, the onion still occupies the third place in respect of acreage in Poland. In the European Union, Poland is the third biggest producer of this vegetable. The percentage share in European production is nearly $10 \%$. Poland exported nearly 125 thousand tons of onion in 2014, mainly to the United Kingdom, Ukraine and the Netherlands (Agencja Rynku Rolnego, 2015). The onion cultivations are mainly attacked by Thrips tabaci Lind. Both larvae as well as adult T. tabaci are highly harmful. Larvae and imago feed on chives using narrow stylet to pierce the cell wall of tissues and suck juice from plant cells, and at the same time introduce to their tissues such compounds like amides, plant hormones and polyphenols oxidase, which cause hyperplasia and hypertrophy of cells through various processes (Lewis, 1973). The leaves become deformed and then dry out. The shortened vegetation period caused by thrips feeding reduces the onion yield. The growing interest in ecological plant protection measures is noticed during the last years. Ethereal oils are one of them. Their usage limits the quantity of chemicals in the environment. Plant essential oils represent a rich source of new pesticides. Active ingredients in the new products include oils of clove, rosemary, mint, and orange. Many plant essential oils show a broad spectrum of activity against pest insects and plant pathogenic fungi ranging from insecticidal, antifeedant, repellent, oviposition deterrent, growth regulatory and antivector activity (Isman, 2006). The goal of the research was to check the influence of orange and cinnamon oil on the occurrence and harmfulness of onion thrips on onion.

\section{Results and discussion}

During 2014-2015, the influence of orange and cinnamon oil on the occurrence and harmfulness of T. tabaci on onion was researched. The research works were conducted at the Experimental Plant Protection station of the University of Agriculture in Cracow, located in Mydlinki (near Cracow). Randomly selected blocks in four replications on the plots with area of $9 \mathrm{~m}^{2}$ were used. The plots were separated by one-meter wide paths. The plots without chemical control were used as a control. The seeds of 'Tęcza' variety cultivar were planted at the end of April.

In 2014, the chemical treatment was made with Prev-B2 (the concentration of $0.4 \%$ ), which contains: $4.2 \%$ of orange oil, $2.1 \%$ of boron and product Canol $70 \% \mathrm{p} / \mathrm{p}$ extract of Cinnamomum zeylanicum. In 2015, only Prev-B2 product was used. The standard sprayer was used and the treatments were done: twice in 2014 (on 21 July and 4 August, three times in 2015 (on 30 June, 11 and 23 July). The product was applied during the evening hours on dry days.

The thrips were caught on onion leaves using standard sweep nets. In 2014, the analysis was conducted in the period from 11 June to 19 August, whereas in 2015, the analysis was performed from 24 June to 4 August. The time span between the analyses was 7 to 10 days. The thrips were also collected directly from leaves. To do this, before each usage of sweeping nets, 10 randomly selected samples were collected. Next, the plants and the collected thrips were analysed in laboratory. The taxonomic identification of thrips was done using microscopes and the key developed by Zawirska (1994). 
Table 1 Infestation of onion cv. 'Tęcza' by Thrips tabaci treated with preparations containing orange and cinnamon oil and onion untreated (control plots), Mydlniki 2014-2015

\begin{tabular}{|l||c|c|c|}
\hline \multirow{2}{*}{ Year } & Combination & \multicolumn{2}{|c|}{ Mean number of T. tabaci } \\
\cline { 2 - 4 } & & collected by sweep net/plot & collected from plants/1 plant \\
\hline \multirow{3}{*}{2014} & orange oil & $14.3 \mathrm{~b}$ & $3.4 \mathrm{a}$ \\
\cline { 2 - 4 } & cinnamon oil & $14.7 \mathrm{~b}$ & $2.7 \mathrm{a}$ \\
\cline { 2 - 4 } & control & $56.8 \mathrm{a}$ & $2.5 \mathrm{a}$ \\
\hline \multirow{2}{*}{$\mathbf{2 0 1 5}$} & orange oil & $129.5 \mathrm{~b}$ & $19.4 \mathrm{a}$ \\
\cline { 2 - 4 } & control & $180.5 \mathrm{a}$ & $22.1 \mathrm{a}$ \\
\hline
\end{tabular}

* Mean values followed by different letters in the same columns are significantly different at $P \leq 0.05$; one-way

The plants were examined to find the leave damages caused by feeding thrips. To do this, three leaves were selected on each plant: external (the oldest), middle and the youngest one. Next, the fragment in the middle of leaf with the length of $10 \mathrm{~cm}$ was taken for analysis of damages on the leaf surface.

The one-way ANOVA and the Duncan test $(P \leq 0.05)$ were performed for the field data to test the differences between the numbers of thrips and the damage to the surface of the leaves. All statistical analyses were performed using the software PASW Statistics 10.0.

\section{Results and discussion}

The results based on the number of thrips collected using sweeping nets show that both orange oil as well as cinnamon oilsignificantlydecreased thenumberofadultsofonionthrips. In 2014, the mean number of thrips on control plots was 4 times greater than on the plots treated with oils (Table 1). In 2015 , this number was higher by $28 \%$. Also, the mean percentage of areas damaged on the onion leaves was significantly higher on control plots than on plots treated with cinnamon oil in 2014 and orange oil in 2015 (Table 2).

In previous studies by Leśniak et al. (2013) the authors found high efficiency of orange oil in controlling of Aphis phomi and Tetranynchus urticae. Also, similar results were obtained by Górski and Kania (2010), who tested the effect of orange oil on mortality of Aulacorthum solani on tobacco. Studies on the effect of rosemary and marjoran essential oils on thrips were carried out by the Koschier et al. (2002)

Table 2 Damage to the surface of the leaves of onion cv. 'Tęcza' by Thrips tabaci on plants treated with preparations containing orange and cinnamon oil and onion untreated (control), Mydlniki 2014-2015

\begin{tabular}{|c|c|c|}
\hline Year & Combination & Mean damaged surface (\%) \\
\hline \multirow{3}{*}{2014} & orange oil & $37.6 \mathrm{ab}$ \\
\hline & cinnamon oil & $31.1 \mathrm{~b}$ \\
\hline & control & $42.5 \mathrm{a}$ \\
\hline \multirow{2}{*}{2015} & orange oil & $15.9 \mathrm{~b}$ \\
\hline & control & $31.7 \mathrm{a}$ \\
\hline
\end{tabular}

and Koschier (2008). The authors found out that they have a repellent effect on feeding and oviposition of T. tabaci.

\section{Conclusions}

Orange and cinnamon oil demonstrated efficacy against Thrips tabaci on onion. Preparations containing these oils should be recommended in protecting onion against thrips.

\section{References}

AGENCJA RYNKU ROLNEGO. 2015. Available at:http://www.ar.gov.p GÓRSKI, R. - KANIA, A. 2010. Wpływ olejków kolendrowego i petitgrain na śmiertelność mszycy ziemniaczanej Aulacorthum solani (Kalt.) występującej na tytoniu. In Progress in Plant Protection, vol. 50, no. 3, pp. 1530-1532. ISSN 1427-4337.

HUANG, Y. - HO, S. H. 1998. Toxicity and antifeedant activities of cinnamaldehyde against the grain storage insects, Tribolium castaneum (Herbst) and Sitophilus zeamais Motsch. In Journal of Stored Products Research vol. 34, no. 1 pp. 11-17. ISSN 0022-474X. ISMAN, M. B. 2006. Botanical insecticides, deterrents, and repellents in modern agriculture and an increasingly regulated world. In Annual Review of Entomology, vol. 56, pp. 45-66. ISSN 0066-4170.

JUMBO, L. O. V. - Faroni, L. R. A. - Olivera, E. E. - Pimentel, M. A. Silva, G. N. 2014. Potential use of clove and cinnamon essential oils to control the bean weevil, Acanthoscelides obtectus Say, in small storage units. In Industrial Crops and Products, vol. 56, pp. 27-34. ISSN 0926-6690.

KOSCHIER, E. H. 2008. Essential oil compounds for thrips control a review. In Natural Products Communication, vol. 3, pp. 11711182. ISSN 1934-578X.

KOSCHIER, E. H. - Sedy, K. A. - Novak, J. 2002. Influence of plant volatiles on feeding damage caused by the onion thrips Thrips tabaci. In Crop Protection, vol. 21, no. 5, pp. 419-425. ISSN 0261-2194.

LEŚNIAK, M. - POBOŻNIAK, M. - PNIAK, M. 2013. The influence of orange oil and orange synthetic aroma on Tetranychus urticae (Koch.), Aphis phomi (Deg.) and Eriosoma lanigerum (Hasm.). In Episteme, vol. 22, pp. 101-107. ISSN 1895-4421.

LEWIS, T. 1973. Thrips their biology, ecology and economic important. London - New York: Academic Press. p. 349. ISBN 0-12447160-9. ISBN 0-12-447160-9.

ZAWIRSKA, I. 1994. Thrips (Thysanoptera). In Diagnostics of plant pests and their natural enemie. (Eds. M. W. Kozłowski \& J. Boczek), Warszawa: SGGW, pp. 145-174. ISBN 83-00-02804-8. 